\title{
Mentoring as one of the Prerequisites for the Development of the Entrepreneurial Environment
}

\author{
Anda Zvaigzne \\ Research Institute for Business and \\ Social Processes Faculty of Economics \\ and Business Management \\ Rezekne Academy of Technologies \\ Rezekne, Latvia \\ anda.zvaigzne@rta.lv
}

\author{
Inta Kotane \\ Research Institute for Business and \\ Social Processes Faculty of Economics \\ and Business Management \\ Rezekne Academy of Technologies \\ Rezekne, Latvia \\ inta.kotane@rta.lv
}

\section{INTRODUCTION}

The quality of the entrepreneurial environment is one of the preconditions for the competitiveness of the national economy of Latvia - the better conditions the government can create for entrepreneurs, the more investment could be made in the national economy, which, in turn, contributes to the creation of new jobs and the standard of living (Ekonomikas ministrija, 2018). A draft of the Plan of Measures for Enhancing the Entrepreneurial Environment announced at a meeting of state secretaries set the following goal: an entrepreneurial environment has to be attractive to entrepreneurs: available and understandable services and a lower administrative burden. The plan is comprised of 12 sections focusing on the entrepreneurial environment or action priorities that involve 47 measures with deadlines of up to three years.

Today, competitiveness and skill to respond to changes fast are the most important factors for entrepreneurship in the regions. In the period 2013-2017, according to the Central Statistical Bureau (CSB) of Latvia, the number of market sector economically active statistical units per 1000 capita in Rezekne municipality was larger than that in Latvia as a whole. In 2017, there were 68 enterprises per 1000 capita in Rezekne municipality, while in Latvia this figure was on average 90 [1].

In 2017, the number of enterprises registered in Rezekne municipality, measured per 1000 capita, totalled 60.69 , which could be viewed as a low indicator compared with Durbe municipality with 146.00 and a relatively high indicator compared with Zilupe municipality with 33.96 [2].

Promoting entrepreneurial activity in rural areas requires a comprehensive approach, which includes retraining of rural residents, providing opportunities for acquiring basic knowledge of entrepreneurship, general economic knowledge and advice [3], and applying experience-sharing methods to develop the entrepreneurial environment [4] - [6]. As indicated by European practices, entrepreneurial experience transfer or mentoring in business is one of the most effective ways how to contribute to the number of new businesses and economic growth [7]. In many countries, mentoring is recognised as a progressive business growth instrument.

Print ISSN 1691-5402

Online ISSN 2256-070X

http://dx.doi.org/10.17770/etr2019vol1.4088

(C) 2019 Anda Zvaigzne, Inta Kotane.

Published by Rezekne Academy of Technologies.

This is an open access article under the Creative Commons Attribution 4.0 International License. 
Transferring successful experience among enterprises, actively sharing knowledge, experience and contacts as well as forming business cooperation culture are the unique values of it. Mentoring is mainly used to contribute to the development of new and less-experienced enterprises [5]. However, it has to be admitted that "mentoring is not a key to success or a solution to all problems only an opportunity to learn the opinion of experienced entrepreneurs and get advice" [8].

The authors believe that despite the expansion of mentoring in Latvia, in Rezekne municipality mentoring in entrepreneurship is practised insufficiently, and it could be one of the ways how to increase the number of new businesses in the municipality.

The research aim is to examine mentoring as one of the preconditions for the development of the entrepreneurial environment.

\section{Specific research tasks:}

1. To examine the conjunctive theoretical aspects of mentoring and entrepreneurial environment development;

2. To assess the results of a survey of mentors and mentees in Rezekne municipality.

Research methods used: monographic and descriptive, analysis, synthesis, statistical analysis and a sociological method - surveying.

The research was done based on relevant research studies by foreign and national scientists as well as industry experts, data of the Central Statistical Bureau (CSB) and other information sources.

To process the data, the research employed SPSS (Statistical Package for the Social Sciences) and Microsoft Excel analysis tools.

\section{MATERIALS AND METHODS}

The research conducted a survey of entrepreneurs - mentors - and mentees with the aim of collecting information and data on the entrepreneurs who wished to participate in the activities of the business mentor network in Rezekne municipality. The questionnaires were distributed electronically, Rezekne municipality enterprise managers were spoken to in person and interviewed via phone as well as the questionnaires were published on the Facebook page of the Rezekne municipality local government. Two kinds of questionnaire were disseminated, appealing to both current entrepreneurs being ready to become mentors as well as future entrepreneurs wishing to learn and get inspired by experienced entrepreneurs. The quantitative survey of entrepreneurs was conducted from November 2018 to January 2019. Among the respondents, women represented $18.2 \%$ and men $81.8 \%$; the highest percentage (36.4\%) was found for the group aged 41-45 who had a Bachelor's degree or second-level professional higher education $(36.4 \%)$ in natural sciences $(36.5 \%)$. Among the mentees, $52.6 \%$ were women and $47.4 \%$ were men; the highest percentage $(31.6 \%)$ was observed for the group aged 26-30 who had a Bachelor's degree or second-level professional higher education in social sciences $(36.5 \%)$.

The surveyed enterprises engaged in mentoring were divided into three categories:

- microenterprises (0-5 employees) $-72.7 \%$ of the total respondents;

- small enterprises (6-10 employees) $-18.2 \%$ of the total respondents;

- medium enterprises(31-40 employees) $-9.1 \%$ of the total respondents.

The participation activity of entrepreneurs (mentors) in the survey was low in Rezekne municipality. Only 11 questionnaires were received back from entrepreneurs (mentors) and 19 from future or new entrepreneurs (mentees).

Based on the information available in public databases and on the Internet, 98 enterprises registered in Rezekne municipality (Table 1) were selected; the enterprises were sent an invitation to participate in the online survey conducted by use of the indirect surveying method (information on the survey was sent to the potential respondents via email, requesting them to fill in a questionnaire electronically on the portal google. com). The invitation was sent twice - in the beginning of November 2018 and in December (the second one was a reminder about the participation in the survey). In view of the low activity of entrepreneurs, the authors made a decision to do interviews by phone, speaking to every potential respondent in person and filing in questionnaires themselves.

TABLE 1. CHARACTERISTICS OF THE SAMPLE REACHED

\begin{tabular}{|l|c|}
\hline Kind of study & Number \\
\hline $\begin{array}{l}\text { Number of email addresses that were sent an invita- } \\
\text { tion to participate in the survey }\end{array}$ & 98 \\
\hline Number of completed web questionnaires & 12 \\
\hline Telephone - the number of interviews & 25 \\
\hline Size of the sample & 37 \\
\hline Number of valid and processed questionnaires & 30 \\
\hline Source: authors'study & \\
\hline
\end{tabular}

To reach a larger number of potential mentees, which could be also represented by entrepreneurs who are establishing their own enterprise or only plan to do it and their contact information is not available publicly, the authors used an opportunity to publish the questionnaires on the Facebook page of the Rezekne municipality local government.

A questionnaire was filled in for every entrepreneur individually (or it was done by the entrepreneur him/ herself). The research group tested the questionnaires received for validity. The questionnaires meeting the quality standards were prepared for data processing and summarisation.

Among the respondents - Rezekne municipality entrepreneurs (mentors) -, the highest percentage was found for those representing enterprises engaged in agriculture, forestry and fisheries, wholesale and retail trade and repair of motor vehicles and motor cycles (27.3\%). Of the respondents, $36.4 \%$ indicated that earlier they worked in another enterprise engaged in the same field of economic activity; $90.9 \%$ noted that besides entrepreneurship they had experience in other fields, the duration of their enterprises was 6-10 years $(45.5 \%)$ and the average number of employees was 0-5 (72.7\%).

As regards the mentees, the highest percentage was 
found for those representing enterprises engaged in agriculture, forestry and fisheries as well as accommodation and food service activities $(21.1 \%)$. Of the respondents, $42.1 \%$ indicated their enterprises were in the process of establishment.

\section{Results AND DISCUSSION}

Mentoring in entrepreneurship represents a systematically shaped relationship based on longterm and voluntary support between a successful entrepreneur sharing his/her knowledge, experience and views and another entrepreneur who is ready and wish to learn it and improve his/her professionalism [9]. Mentoring is generally a oneto-one interrelation that normally occurs between a senior, more experienced person (the mentor), and a junior less skilled one (the mentee) to help the mentee to effectively and rapidly adapt to the business environment through advice and guidance so that mentees acquire organizational socialization, career advancement and professional and personal growth [10].

Mentoring is the relationship between a person with advanced experience and knowledge and a more junior person who seeks assistance, guidance and support for their career, personal and professional development [11].

Mentoring is a long-term relationship between a mentor and a mentee that meets the need for development, helps to unlock the mentee's full potential and benefits all the parties involved. A mentor individually works with an enterprise to assess its business performance and problems or opportunities for developing its potential, give advice and recommendations on business expansion and particular action [12].

Scientists have researched various factors affecting the quality of mentoring. The researchers [13] believe that trust is an essential component of effective mentoring relationships, and mentoring programmes have to include activities helping to build up and promote trust between a mentor and a mentee. Researching the prototypes of an ideal mentor, the researchers [14] pointed out that when asked about their ideal mentor, the respondents stressed the guidance given by the mentor, interpersonal "warmth" and his/her ethical integrity. The prototypes of an ideal mentor varied, depending on ethnicity and gender, and also on how the question was asked. The researchers [15] identified 29 mentor characteristics (age, gender, work experience, motivation to be a mentor etc.). The practice showed [16] that there was no statistically significant difference in clients' satisfaction according to whether an entrepreneur worked with a mentor of the same gender. In the case of small enterprises, mentees, first of all, wanted a mentor who listened to them, and who accurately assessed their particular business situation. They wanted a mentor who was helpful and who provided relevant advice in a respectful manner.

The authors conclude that mentoring is a knowledge transfer process implemented by experienced mentors and mentees. Mentoring in entrepreneurship is based on the mentor's knowledge and experience, which allows the mentee to assess the opportunities and resources being at his/her disposable and use them to solve some particular problem or achieve a goal.

Globally, entrepreneurship plays a significant role in employment creation. When entrepreneurs succeed, economies thrive. They therefore need a support system that nurtures their potential and an environment suitable for sustainable entrepreneurship to take place. One of the key components that entrepreneurs could benefit from is mentoring. However, the understanding around mentorship, its benefits and impact is still not widespread across most developing nations [17]. The strong relationship between the mentor and the mentee create a safe environment for the growth and development of the mentee [18].

Mentoring does not just help young professionals gain the experience and wisdom they need in the workforce, it can also increase the likelihood of small business success. Working with a mentor at least five times greatly increases an entrepreneur's likelihood of business success. It has to be noted that the top three issues entrepreneurs asked their mentors for help with were: human resource issues $(61 \%)$; growth/business expansion (59\%) and startup assistance (53\%) [19].

The authors agree with the above-mentioned assertions and believe that mentoring is one of the most effective ways how to contribute to the number of new entrepreneurs and economic growth. Overall, entrepreneurship expands and develops if experienced entrepreneurs give guidance to beginners in entrepreneurship. Mentoring positively affects the national economy, as new enterprises are founded, unemployment declines and the competitiveness of enterprises increases.

The survey of entrepreneurs (mentors) done within the present research revealed that the potential mentors rated the importance of knowledge a mentor needs (Table 2) as "important" and "very important" and admitted they were competent in business legislation, $90.91 \%$ and $9.9 \%$, respectively. The knowledge of how to enter a new market and attract a new cooperation partner was rated as "important" by $81.82 \%$ and as "very important" by $18.18 \%$ respondents.

TABLE 2. RATINGS OF IMPORTANCE OF KNOWLEDGE NEEDED BY A MENTOR IN REZEKNE MUNICIPALITY, SURVEY OF MENTORS ( $\mathrm{N}=11), \%$

\begin{tabular}{|l|c|c|c|c|c|}
\hline & $\begin{array}{c}\text { Very } \\
\text { im- } \\
\text { port- } \\
\text { ant }\end{array}$ & $\begin{array}{c}\text { Im- } \\
\text { port- } \\
\text { ant }\end{array}$ & $\begin{array}{c}\text { Not im- } \\
\text { portant }\end{array}$ & $\begin{array}{c}\text { No } \\
\text { opin- } \\
\text { ion }\end{array}$ & Total \\
\hline Accounting & 18.18 & 54.55 & 27.27 & - & 100.00 \\
\hline Marketing & 18.18 & 63.64 & 9.09 & 9.09 & 100.00 \\
\hline $\begin{array}{l}\text { Entry into new } \\
\text { markets, new } \\
\text { cooperation } \\
\text { partners }\end{array}$ & 18.18 & 81.82 & - & - & 100.00 \\
\hline $\begin{array}{l}\text { Personnel } \\
\text { management }\end{array}$ & 9.09 & 54.55 & 18.18 & 18.18 & 100.00 \\
\hline $\begin{array}{l}\text { Business } \\
\text { legislation }\end{array}$ & 9.09 & 90.91 & & & 100.00 \\
\hline
\end{tabular}




\begin{tabular}{|l|l|l|l|l|l|}
\hline $\begin{array}{l}\text { Establishment } \\
\text { of a new } \\
\text { enterprise } \\
\text { and business } \\
\text { start-up }\end{array}$ & 9.09 & 54.55 & 27.27 & 9.09 & 100.00 \\
\hline $\begin{array}{l}\text { Development } \\
\text { of a business } \\
\text { plan, project }\end{array}$ & 18.18 & 72.73 & 9.09 & 100.00 \\
\hline
\end{tabular}

An assessment of the problems the mentees would like to solve with the help of their mentors highlighted the overall problems of the entrepreneurial environment in Latgale region. Of the respondents, $21.6 \%$ wished to make new contacts and cooperation partners (Table 3), while $17.6 \%$ hoped to attract investments and financial resources for their enterprises with the help of their mentors; $11.8 \%$ expected that their mentors would reveal their personal potential and how to use it for business expansion. The mentees relatively rarely chose the reply option "Sufficiency of current assets" and "Use of technologies at work" $(2 \%)$.

TABLE 3. ASSISTANCE IN SOLVING THE MOST ESSENTIAL PROBLEMS THANKS TO COOPERATION WITH MENTORS ( $\mathrm{N}=19)$, (RESPONDENTS COULD CHOOSE SEVERAL REPLY OPTIONS)

\begin{tabular}{|c|c|c|c|}
\hline \multirow[b]{2}{*}{ Problem solutions a } & \multicolumn{2}{|c|}{ Replies } & \multirow{2}{*}{$\begin{array}{c}\text { Occur- } \\
\text { rence } \\
\text { frequency, } \\
\%\end{array}$} \\
\hline & $\begin{array}{l}\text { Num- } \\
\text { ber }\end{array}$ & $\%$ of total & \\
\hline $\begin{array}{l}\text { New contacts and coop- } \\
\text { eration partners }\end{array}$ & 11 & 21.6 & 57.9 \\
\hline $\begin{array}{l}\text { Attraction of invest- } \\
\text { ments, funds for the } \\
\text { enterprise }\end{array}$ & 9 & 17.6 & 47.4 \\
\hline $\begin{array}{l}\text { Problems related to } \\
\text { sales, demand for goods } \\
\text { and services }\end{array}$ & 6 & 11.8 & 31.6 \\
\hline $\begin{array}{l}\text { Sufficiency of current } \\
\text { assets }\end{array}$ & 2 & 3.9 & 10.5 \\
\hline Personnel & 3 & 5.9 & 15.8 \\
\hline $\begin{array}{l}\text { Use of technologies at } \\
\text { work }\end{array}$ & 1 & 2.0 & 5.3 \\
\hline Imports/ exports & 3 & 5.9 & 15.8 \\
\hline $\begin{array}{l}\text { Promotion of career } \\
\text { growth }\end{array}$ & 1 & 2.0 & 5.3 \\
\hline $\begin{array}{l}\text { Build-up of knowledge } \\
\text { of entrepreneurship }\end{array}$ & 5 & 9.8 & 26.3 \\
\hline $\begin{array}{l}\text { Revelation of personal } \\
\text { potential and effective } \\
\text { use of the potential in } \\
\text { business expansion }\end{array}$ & 6 & 11.8 & 31.6 \\
\hline Others & 4 & 7.8 & 21.1 \\
\hline Total: & 51 & 100.0 & 268.4 \\
\hline
\end{tabular}

${ }^{\mathrm{a}}$ Dichotomy group tabulated at value 1

Source: authors' calculations

L.Straujuma has pointed out that the professional quality of labour and enterprise productivity represent the key challenges to further economic growth in Latgale region. The quality of labour does not meet labour market requirements [20]. Reports on emigration give the same evidence - the most educated residents emigrate from Latgale region [21]. In this regard, a special attention has to be paid to a survey that revealed that the respondents did not consider labour and personnel problems to be important or urgent. Only 5.9\% respondents believed it was a problem in Rezekne municipality. The authors explain it by a lack of experience in new entrepreneurs and the fact that $72.7 \%$ respondents represented small enterprises with employees ranging from 0 to 5 .

To build up trust, a mentor has to demonstrate openness, honesty and frankness. Openness creates confidence and trust. However, mentoring is a two-way communication process whereby both sides benefit; therefore, potential mentors were asked a question "What traits do you expect from/consider important in a mentee?" (Table 4).

TABLE 4. TRAITS MENTORS EXPECT FROM /CONSIDER IMPORTANT IN MENTEES ( $\mathrm{N}=11$ ), (RESPONDENTS COULD CHOOSE SEVERAL REPLY OPTIONS)

\begin{tabular}{|c|c|c|c|}
\hline \multirow[b]{2}{*}{ Traits a } & \multicolumn{2}{|c|}{ Replies } & \multirow{2}{*}{$\begin{array}{c}\text { Occur- } \\
\text { rence } \\
\text { frequency, } \\
\quad \%\end{array}$} \\
\hline & $\begin{array}{c}\text { Num- } \\
\text { ber }\end{array}$ & $\begin{array}{l}\% \text { of } \\
\text { total }\end{array}$ & \\
\hline $\begin{array}{l}\text { Openness, friendliness, } \\
\text { readiness to cooperate }\end{array}$ & 8 & 25.8 & 72.7 \\
\hline $\begin{array}{l}\text { Mentees share their } \\
\text { thoughts and feelings }\end{array}$ & 4 & 12.9 & 36.4 \\
\hline $\begin{array}{l}\text { Mentees reveal their } \\
\text { personalities and roles } \\
\text { in their enterprises to } \\
\text { their mentors }\end{array}$ & 4 & 12.9 & 36.4 \\
\hline $\begin{array}{l}\text { Mentees are able to } \\
\text { assume responsibility } \\
\text { for their training and } \\
\text { cooperation }\end{array}$ & 2 & 6.5 & 18.2 \\
\hline $\begin{array}{l}\text { Mentees give feedback } \\
\text { to their mentors on the } \\
\text { activities done and the } \\
\text { effects }\end{array}$ & 5 & 16.1 & 45.5 \\
\hline $\begin{array}{l}\text { Mentees are able to } \\
\text { accept and use the } \\
\text { challenges that have } \\
\text { emerged during mento- } \\
\text { ring for their growth }\end{array}$ & 5 & 16.1 & 45.5 \\
\hline Others & 3 & 9.7 & 27.3 \\
\hline Total: & 31 & 100.0 & 281.8 \\
\hline
\end{tabular}

Source: authors' calculations

Of the respondents, $25.8 \%$ considered "Openness, friendliness, readiness to cooperate" to be the most important trait of mentees. It was followed by "Mentees share their thoughts and feelings" and "Mentees reveal their personalities and roles in their enterprises to their mentors". The replies are consistent with what mentoring theory states - the role of mentors does not involve tackling mentees' problems instead of them. Mentors have to hear and listen and help mentees to find answers to problems themselves. This is a serious problem for mentors themselves.

The authors have found that mentoring in entrepreneurship in Rezekne municipality could contribute to the development of less-experienced enterprises. Mutual communication between potential mentors and mentees could avoid a lack of information and advice for the mentees and sharing experience could contribute to their initiative. Accordingly, it is necessary to continue the research begun by the authors, identifying and creating a database of potential mentors and mentees in the other municipalities of Latgale region who are 
ready to engage in the business mentor network.

\section{Conclusions}

Mentoring is a knowledge transfer process implemented by experienced mentors and mentees. Mentoring in entrepreneurship is based on the mentor's knowledge and experience, which allows the mentee to assess the opportunities and resources being at his/her disposable and use them to solve some particular problem or achieve a goal.

Mentoring is one of the most effective ways how to contribute to the number of new businesses and economic growth. Overall, entrepreneurship expands and develops if experienced entrepreneurs give guidance to beginners in entrepreneurship. Mentoring positively affects the national economy, as new enterprises are founded, unemployment declines and the competitiveness of enterprises increases.

The survey of entrepreneurs (mentors) done within the present research revealed that the potential mentors rated a mentor's knowledge of relevant business legislation and how to enter a new market and attract a new cooperation partner as "important" and "very important".

An assessment of the problems the mentees would like to solve with the help of their mentors highlighted the overall problems of the entrepreneurial environment in Latgale region. The mentees wished to make new contacts, acquire new cooperation partners and attract investments and funds with the help of their mentors as well as expected that their mentors would help them to reveal their personal potential and how to effectively use it in entrepreneurship. The key traits needed by mentees, the potential mentors referred to, confirmed the theoretical principles of mentoring - mentors have to hear and listen and to help their mentees to find answers to problems themselves.

Mentoring in entrepreneurship in Rezekne municipality could contribute to the development of lessexperienced enterprises. Accordingly, it is necessary to continue the research begun by the authors, identifying and creating a database of potential mentors and mentees in the other municipalities of Latgale region who can and are ready to engage in the business mentor network.

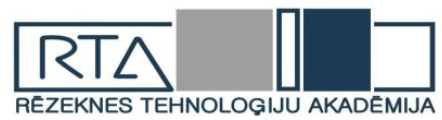

The paper was produced with the financial support of Rezekne Academy of Technologies from the research grant "Mentoring Opportunities for Entrepreneurship Development in Rezekne Municipality".

\section{REFERENCES}

[1] Central Statistical Bureau database, ,Economically active enterprises of market sector in statistical regions, cities under state jurisdiction and counties per 1000 inhabitants," 2018. [Online]. Available: https://data1.csb.gov.lv/pxweb/lv/uzn/uzn 01 skaits/ SRG040.px/table/tableViewLayout1/?rxid=elbf26f4-e4a $\overline{6}-4233-$ 87b4-ede771fc26a5 [Accessed February 20, 2019]

[2] "Visvairāk uzṇēmumu uz 1000 iedzīvotājiem - Durbes novadā," November 2018. [Online]. Available: http://blog.lursoft. lv/2018/11/07/visvairak-uznemumu-uz-1000-iedzivotajiemdurbes-novada/ [Accessed February 20, 2019]

[3] R.Zvirgzdiṇa, "Uzṇēmējdarb̄̄bas aktivizēšana lauku reǵionos globalizācijas kontekstā”, Economic Science for Rural Development, No. 10, pp. 227-233, 2006.

[4] Latvijas Universitāte, ,Mentoru rokasgrāmata,” 2018. [Online].
Available: https://skolas.lu.lv/mod/resource/view.php?id=20582 [Accessed February 20, 2019]

[5] Latvijas Investīciju un attīstības aǵentūra, ,Biznesa mentoru tīkla rokasgrāmata mentoriem un pieredzes pārn̄ēmējiem," 2012. [Online]. Available: http://new.llkc.lv/sites/default/files/baskik p/pielikumi/mentorings-vadlinijas.pdf [Accessed February 20, 2019]

[6] Attīstības finanšu institūcija Altum, „ALTUM pētījums: Iesaistoties uzn̄ēmējdarbībā, uzlabojas apmierinātība ar dzīvi un finansiālā situācija," May 2017. [Online]. Available: https://www. altum.lv/lv/jaunumi/-altum-petijums-iesaistoties-uznemejdarbiba-uzlabojas-apmierinatiba-ar-dzivi-un-finansiala-situacija. [Accessed February 20, 2019]

[7] B.Rivža, „Kā lauku sievietei kḷūt par uzṇēmēju,” February 8, 2006. [Online]. Available: http://www.kvestnesis.lv/body print. php?id=127534 [Accessed February 20, 2019]

[8] A.Asere, "Mentorings palīdz iemācīties domāt kā uzṇēmējam," Dienas Bizness, September 26, 2011.

[9] E.Konstantinova, Mentoringa kustības rokasgrāmata. LLU, 2007, 112 p.

[10] K.N.Gisbert-Trejo, J.Landeta, E.Albizu, P.Fernández-Ferrín, „Determining effective mentor characteristics in inter-organizational mentoring for managers: an approach based on academics' and practitioners' perspectives," Industrial and Commercial Training, vol. 51 issue: 2, pp.85-103, 2019, Available: www.emeraldinsight. com/, [Accessed February 20, 2019], https://doi.org/10.1108/ICT$\underline{06-2018-0051}$

[11] J.L.Fowler, J.G.O'Gorman, „Mentoring Functions: A Contemporary View of the Perceptions of Mentees and Mentors," British Journal of Management, vol.16, pp.51-57, February 2005, Available: https://onlinelibrary.wiley.com/doi/abs/10.1111/j.14678551.2005.00439.x [Accessed February 10, 2019], https://doi. org/10.1111/j.1467-8551.2005.00439.x

[12] Norvēǵijas finanšu instrumenta programma, „Rokasgrāmata Latvijas pašvaldību darbiniekiem vietējās ekonomikas attīstības sekmēšana," 2014. [Online]. Available: https://goo.gl/1usYK4 [Accessed February 20, 2019]

[13] J.Leck, B.Orser, „Fostering trust in mentoring relationships: an exploratory study," Equality, Diversity and Inclusion: An International Journal, vol.32, issue:4, pp.410-425, 2013, Available: www. emeraldinsight.com/, [Accessed February 20, 2019], https://doi. org/10.1108/EDI-01-2010-0007

[14] S.F.Bailey, E.C.Voyles, L.Finkelstein, K.Matarazzo, ,Who is your ideal mentor? An exploratory study of mentor prototypes," Career Development International, vol.21, issue:2, pp.160-175, January 2016. Available: www.emeraldinsight.com/ [Accessed February 20, 2019], https://doi.org/10.1108/CDI-08-2014-0116

[15] K.N.Gisbert-Trejo, J.Landeta, E.Albizu, P.Fernández-Ferrín, „Determining effective mentor characteristics in inter-organizational mentoring for managers: an approach based on academics' and practitioners' perspectives," Industrial and Commercial Training, vol. 51 issue: 2, pp.85-103, 2019, Available: www.emeraldinsight. com/, [Accessed February 20, 2019], https://doi.org/10.1108/ICT06-2018-0051

[16] I.M.O’Bannon, „Business Mentoring Increases Small Business Survival Rates,". Jun 2018. [Online]. Available: https://www. cpapracticeadvisor.com/news/12415443/business-mentoring-increases-small-business-survival-rates [Accessed February 20, 2019]

[17] A.Wachira, "Mentoring the next generation of entrepreneurs," January 2018. [Online]. Available: https://biasharaleo.co.ke/index.php/2018/01/09/mentoring-the-next-generation-of-entrepreneurs/ [Accessed February 20, 2019]

[18] R.Sullivan, „Entrepreneurial learning and mentoring,” International Journal of Entrepreneurial Behavior \& Research, vol.6, issue:3, p.160-175, 2000, Available: www.emeraldinsight.com/, [Accessed February 20, 2019], https://doi. org/10.1108/13552550010346587

[19] I.M.O’Bannon, „Business Mentoring Increases Small Business Survival Rates," Jun 2018. [Online]. Available: https://www. cpapracticeadvisor.com/news/12415443/business-mentoring-increases-small-business-survival-rates [Accessed February 20, 2019]

[20] L.Straujuma, „Latgales regiona ekonomikas attīstība”, May 2017. [Online]. Available: https://www.researchgate.net/publication/318638546_LATGALES REGIONA_EKONOMIKAS_ATTISTIBA [Accessed February 20, 2019]

[21] „Imigrācijas loma darbaspēka nodrošinājumā Latvijā,” (Role of Immigration in the Supply of Labour in Latvia) April 2018. [Online]. Available: http://www.saeima.lv/petijumi/Imigracijas loma darbaspeka nodrosinajums Latvija-2018 aprilis.pdf [Accesse $\bar{d}$ February 20, 2019] 